\title{
Effect of limited mating on the corpora lutea in montane voles, Microtus montanus
}

\author{
Ann McM. Kenney and D. A. Dewsbury \\ Department of Psychology, University of Florida, Gainesville, \\ Florida 32611, U.S.A.
}

Conaway (1971) has distinguished 3 basic types of reproductive cycles displayed by nonpregnant female mammals. In the first type (e.g. in some hystricomorph rodents and higher primates), both ovulation and pseudopregnancy, defined as a functional luteal phase in a nonpregnant cycle, occur spontaneously. In animals with the second type of cycle (e.g. cats, rabbits) ovulation is induced and pseudopregnancy is spontaneous; the luteal phase following hormone-induced ovulation is indistinguishable from that following copulation. Rats and mice typify a third type of cycle in that ovulation is spontaneous, but the luteal phase is dependent upon copulatory stimulation. Recently, Milligan $(1974,1975)$ has reported a fourth variation: in Microtus agrestis low levels of copulatory stimulation induce ovulation, but the resulting corpora lutea $(\mathrm{CL})$ degenerate about the $3 \mathrm{rd}$ day after mating, i.e. ovulation and activation of functional $\mathrm{CL}$ are dependent on copulation.

Induced ovulation has been demonstrated for several species of Microtus (Greenwald, 1956; Austin, 1957; Richmond \& Conaway, 1969; Clulow \& Mallory, 1970; Cross, 1972; Gray, Davis, Zerylnick \& Dewsbury, 1974a; Gray, Zerylnick, Davis \& Dewsbury, 1974b), but the precise requirements for the development of luteal function have been determined only for $M$. agrestis. No dissociation between the occurrence of ovulation and of functional CL has been found in $M$. ochrogaster (Kenney, Lanier \& Dewsbury, 1977).

Because $M$. agrestis and $M$. montanus are reproductively similar in many other ways [e.g. large amounts of copulatory stimulation (Davis, Gray, Zerlynick \& Dewsbury, 1974; Milligan, 1975); high LH levels after copulation (Charlton, Naftolin, Sood \& Worth, 1975; Gray, Davis, Kenney \& Dewsbury, 1976); occasional ovulation when separated from the male by a wire-mesh barrier (Gray et al., 1974a; Milligan, 1974)], the influence of a limited amount of mating on luteal development of montane voles was examined.

All animals were laboratory-bred and had produced at least one litter. They were maintained on a reversed $16 \mathrm{~h}$ light: $8 \mathrm{~h}$ dark cycle, and were given free access to Purina rabbit chow and water. Twenty female M. montanus, 3-6 months of age, were used. Fourteen males served as mating partners, and no male was used more than once in a group. Females were brought into oestrus by being placed opposite a male in a $48 \times 27 \times 13 \mathrm{~cm}$ divided cage. Daily vaginal smears were taken with a wire loop. Mating tests were initiated by placing the female in the $29 \times 19 \times 13 \mathrm{~cm}$ home cage of the male. If the female was judged unreceptive or the male failed to achieve intromission within $15 \mathrm{~min}$ the test was discontinued and discounted. Mating occurred about $2 \mathrm{~h}$ into the dark phase of the light cycle, on the 2 nd day of vaginal oestrus (more than $50 \%$ cornified cells). After a positive mating test, the female remained in the male's cage, and the male was removed. Microtus montanus males have a mean ejaculation frequency of 5.0 preceding attainment of a satiety criterion (Dewsbury, 1973), and the proportion of females ovulating increases with the number of ejaculatory series received $(100 \%$ ovulation following 3 or more ejaculations). Because one ejaculatory series does not consistently result in the production of CL that are maintained until Day 8 (Davis et al., 1974), the mating stimulus was limited to one ejaculatory series. Females were killed on the 3rd (Group 1) or 8th (Group 2) day after mating. Ovaries and uteri were examined under a dissecting microscope and the number of CL in each ovary was recorded. To verify accuracy of CL counts, several ovaries were embedded in paraffin wax, serially sectioned at $10 \mu \mathrm{m}$, stained with haematoxylin and eosin and examined microscopically.

Of the 10 females killed on Day 3 (Group 1), 7 had well-developed CL (mean 4.3 $\pm 0 \cdot 6$ (S.E.M.)). In contrast CL (6) and implanted embryos (5) were present 8 days after copulation in only 1 of the 
10 females in Group 2, and this difference in CL frequency was significant $\left(\chi^{2}=7 \cdot 5, P<0 \cdot 01\right)$. There was no difference in the amount of stimulation received by females in the two groups, the mean no. of intravaginal thrusts/test being $58.4 \pm 4.2$ for Day 3 and $62.1 \pm 6.4$ for Day 8 . Similarly, there was no difference in number of thrusts received by females exhibiting CL at examination $(59.5 \pm 5.0)$ and those in which no CL were present $(60 \cdot 8 \pm 5 \cdot 4)$.

Montane voles are therefore like field voles in that limited amounts of mating produce ovulation and the resulting $\mathrm{CL}$ are short-lived. It is important to know which reflexly ovulating mammals show independence of ovulation and the formation of functional CL, as well as the correlates and adaptive significance of this dissociation.

This research was supported by NSF Grant BMS75-08658 to D.A.D. A.McM.K. was supported by NICHD Postdoctoral Research Grant 5 F22 HD 01819-02. We thank Barbara McGuire and the Center for Neurobiological Sciences for histological preparation of ovaries.

\section{References}

Austin, C.R. (1957) Oestrus and ovulation in the field vole (Microtus agrestis). J. Endocr. 15, iv.

Charlton, H.M., Naftolin, F., Sood, M.C. \& Worth, R.W. (1975) The effect of mating upon LH release in male and female voles of the species Microtus agrestis. J. Reprod. Fert. 42, 167-170.

Clulow, F.V. \& Mallory, F.F. (1970) Oestrus and induced ovulation in the meadow vole, Microtus pennsylvanicus. J. Reprod. Fert. 23, 341-343.

Conaway, C.H. (1971) Ecological adaptation and mammalian reproduction. Biol. Reprod. 4, 239-247.

Cross, P. (1972) Observations on the induction of ovulation in Microtus montanus. J. Mammal. 53, 210-211.

Davis, H.N., Gray, G.D., Zerylnick, M. \& DewsBURY, D.A. (1974) Ovulation and implantation in montane voles (Microtus montanus) as a function of varying amounts of copulatory stimulation. Horm. \& Behav. 5, 383-388.

DEWSBURY, D.A. (1973) Copulatory behavior \& montane voles (Microtus montanus). Behaviour 44, 186202.

Gray, G.D., DAvis, H.N., ZeRYlNICK, M. \& DewSBURY, D.A. (1974a) Oestrus and induced ovulation in montane voles. J. Reprod. Fert. 38, 193-196.
Gray, G.D., ZerYlNiCK, M., DAvis, H.N. \& DewsbuRY, D.A. (1974b) Effects of variations in male copulatory behavior on ovulation and implantation in prairie voles, Microtus ochrogaster. Horm. \& Behav. 5, 389396.

Gray, G.D., Davis, H.N., KenNeY, A.MCM. \& Dewsbury, D.A. (1976) The effect of mating on plasma levels of $\mathrm{LH}$ and progesterone in montane voles (Microtus montanus). J. Reprod. Fert. 47, 89-91.

GreENWALD, G.S. (1956) The reproductive cycle of the field mouse (Microtus californicus). J. Mammal. 37, 213-222.

Kenney, A.McM., Lanier, D.L. \& Dewsbury, D.A. (1977) Effects of vaginal-cervical stimulation in seven species of muroid rodent. J. Reprod. Fert. 49, 305-309.

MILligaN, S.R. (1974) Social environment and ovulation in the vole, Microtus agrestis. J. Reprod. Fert. 41, $35-47$.

Milligan, S.R. (1975) Mating, ovulation and corpus luteum function in the vole, Microtus agrestis. $J$. Reprod. Fert. 42, 35-44.

RICHMOND, M. \& CONAWAY, C.H. (1969) Induced ovulation and oestrus in Microtus ochrogaster. $J$. Reprod. Fert., Suppl. 6, 357-376.

Received 4 August 1976 